\title{
FORTHCOMING IASE CONFERENCES
}

\author{
$6^{\text {th }}$ WORLD STATISTICS CONGRESS OF THE ISI \\ Marrakech, Morocco, 16-21 July, 2017

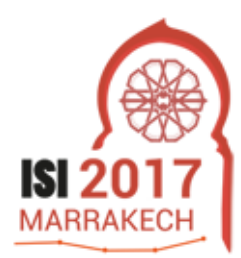 \\ Many invited paper sessions are related to statistics education. \\ For more details, see SERJ 15(2), or www.isi2017.org/.

\section{IASE SATELLITE CONFERENCE “TEACHING STATISTICS IN A DATA-RICH WORLD”} \\ Rabat, Morocco, 11-14 July, 2017
}

The theme of the IASE Satellite Conference is Teaching Statistics in a Data-Rich World. Big data and socially responsible societies will play a key role. Note also the session on employability and the special session on statistics education in Africa.

More information: iase-web.org/conference/satellite17/.

\section{TENTH INTERNATIONAL CONFERENCE ON TEACHING STATISTICS (ICOTS 10)}

Kyoto, Japan, 8-13 July, 2018

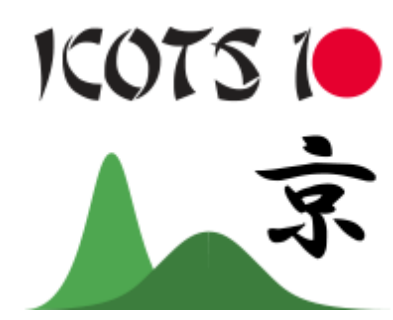

The 10th International Conference on Teaching Statistics (ICOTS 10) will be held at the Kyoto TERRSA, in the centre of Kyoto, Japan.

The International Program Committee, led by Katie Makar, has announced the theme "Looking back, looking forward" and ten major topics:

1. Statistics education: Looking back, looking forward.

2. Statistics education at the school level.

3. Statistics education at the post-secondary level.

4. Improving teaching and capacity in statistics education.

5. Statistics education in the workplace, government and across disciplines.

6. Innovations in teaching probability.

7. Statistical literacy in the wider society.

8. New approaches to research in statistics education.

9. Technology and multimedia in statistics education.

10. Organisations and collaboration in statistics education.

If you are considering organising a session with multiple presenters within one of these topics, please note that the initial proposal deadline is currently scheduled for 31 July 2017. A more formal call will appear soon.

More information: icots.info/10/

Statistics Education Research Journal, 16(1), 224-230, http://iase-web.org/Publications.php?p=SERJ

(C) International Association for Statistical Education (IASE/ISI), May, 2017 


\title{
PAST IASE CONFERENCES
}

None since the 2016 IASE ROUNDTABLE "PROMOTING UNDERSTANDING OF STATISTICS ABOUT SOCIETY” in Berlin (July, 2016).

\section{OTHER FORTHCOMING CONFERENCES}

\author{
VI BAHIAN FORUM ON MATHEMATICS EDUCATION \\ (ENCONTRO BAIANO DE EDUCAÇÃO MATEMÁTICA)
}

Universidade do Estado da Bahia, Alagoinhas, Brazil, 7-9 June, 2017

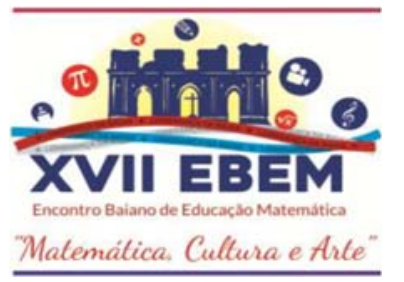

Beside topics on epistemological obstacles for the construction of mathematical concepts and on the potential of the history of mathematics for the process of learning mathematics, there will be a round table on statistics education and its contribution to teaching critical thinking with C. Ferreira Mercês, I. Maurício Cazorla, and Cileda de Queiroz on the panel.

More information: xviiebem.com/.

2017 ANNUAL MEETING OF THE STATISTICAL SOCIETY OF CANADA

University of Manitoba, Winnipeg, Canada, 11-14 June, 2017

The SSC conference will include special seminars and presentations from the Statistical Education Section. There will also be a student conference.

More information: ssc.ca/en/meetings/2017-annual-meeting.

\section{STATISTICS AND DATA SCIENCE: NEW CHALLENGES, NEW GENERATIONS}

University of Florence, Italy, 28-30 June, 2017

Statistics and Data Science: new challenges, new generations Florence 28-30 June
The conference aims to highlight the crucial role of statistics in data science. In this new domain of 'meaning' extracted from the data, the increasing amount of produced and available data in databases has brought new challenges. That involves different fields of statistics, machine learning, information and computer science, optimisation, pattern recognition. These fields together contribute in the analysis of big data, open data, relational and complex data (structured and non-structured). The interest is to collect the contributions from the different domains of statistics: highdimensional data quality validation, sampling extraction, dimensional reduction, pattern selection, data modelling, testing hypotheses, and confirming conclusions drawn from the data. Statistics has become a basic skill in data science: it gives right meaning to the data. It is not replaced by newer techniques from machine learning and other disciplines but it complements them.

More information: meetings3.sis-statistica.org/index.php/sis2017/sis2017. 


\section{STATISTICAL REASONING, THINKING AND LITERACY RESEARCH FORUM (SRTL 10)}

Rotorua, New Zealand, 2-8 July, 2017

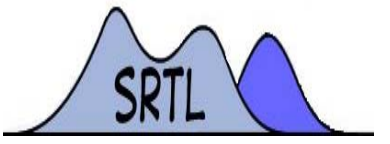

The conference theme is: Innovations in statistical modelling to connect data, chance and content.

More information: blogs.uni-paderborn.de/srtl/srtl-10-2/.

\section{MATHEMATICS EDUCATION BEYOND 16: PATHWAYS AND TRANSITIONS}

University of Birmingham, Birmingham, UK, 10-12 July, 2017

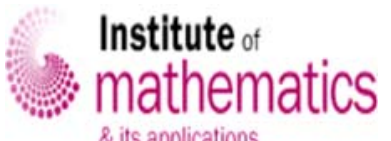

This conference provides a forum for sharing, discussing and developing ideas, research and practice in this rapidly changing landscape. There are quite a few questions that concern the mutual relations between mathematics and statistics: The role of applications and problem solving; The role of technology; Effective ways of evaluating the effectiveness of learning support.

More information in SERJ 15(2), or:

www.ima.org.uk/conferences/conferences_calendar/mathematics-education-beyond-16-

pathways-transitions.html.

\section{CONGRESO IBEROAMERICANO DE EDUCACIÓN MATEMÁTICA}

Universidad Complutense de Madrid, Espana, 10-14 July, 2017

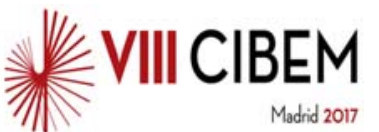

The largest congress on mathematics education in the Latin world has several activities also in statistics education. More information: www.cibem.org/index.php/es/.

\section{DATA SCIENCE, STATISTICS \& VISUALISATION (DSSV 2017)}

Instituto Superior Técnico (IST), Lisboa, 12-14 July, 2017

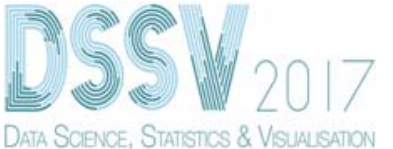

The International Association for Statistical Computing organises a satellite of the World Statistics Congress in Marrakech. The aim is to bring together researchers and statistics and visualisation. professionals interested in the interplay of computer science,

More information: iasc-isi.org/dssv2017/.

\section{ANNUAL CONFERENCE OF THE INTERNATIONAL GROUP FOR THE PSYCHOLOGY OF MATHEMATICS EDUCATION (PME 41) \\ Singapore, 17-22 July, 2017}

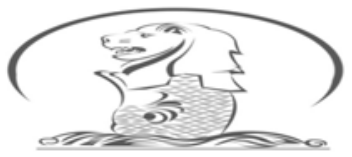

The topic of the 2017 conference is Mathematics Education Research - Learning, Instruction, Outcomes \& Nexus.

Information: www.igpme.org/index.php/annual-conference. 
2017 JOINT STATISTICAL MEETINGS

Baltimore Convention Center, Baltimore, MD, USA, 29 July-3 August, 2017

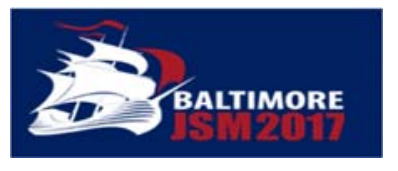

Theme of this year's conference is Statistics: It's Essential. As in other years, there will be a strong and influential session on statistics education organised by the Section on Statistical Education of the American Statistical Society. More information in SERJ 15(2), or: ww2.amstat.org/meetings/jsm/2017/.

\section{REUNIÓN LATINOAMERICANA DE MATEMÁTICA EDUCATIVA} (RELME 31)

Universidad de Lima, Peru, 31 July-4 August, 2017

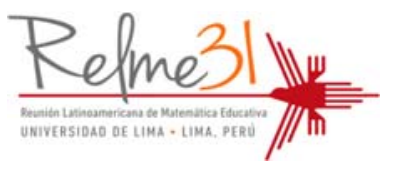

These conferences on mathematics education host quite a few sessions that might interest researchers in statistics education; to name a few: Visualisation, Thinking related to probability and statistics, Advanced technology, Mathematical language.

More information in SERJ 15(2), or: relme31.ulima.edu.pe.

RSS 2017 ANNUAL CONFERENCE

University of Strathclyde, Glasgow, Scotland 4-7 September, 2017

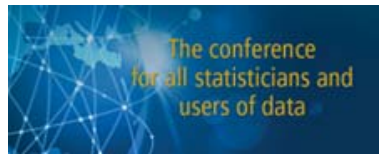

This conference for all statisticians and users of data is unique by the varied programme and participants.

More information in SERJ 15(2), or:

www.rss.org.uk/RSS/Events/RSS_Conference/2017_Conference/RSS/Events/Conference $/ 2017$ conference.aspx?hkey=2a432b6b-6baf-4bc3-baa4-063221c13ab8.

\section{COLLOQUE FRANCOPHONE INTERNATIONAL SUR L'ENSEIGNEMENT DE LA STATISTIQUE (CFIES)}

Grenoble, France, 6-8 September, 2017

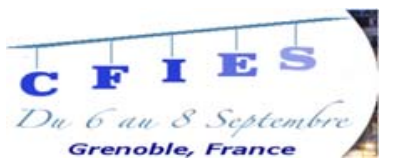

This conference tries to consolidate current trends in statistics education at high-school level: New methods for teaching, evaluation of the reform, continuing professional development, history, and public space. Of special interest is the session on education of statistics in the era of data science.

More information in SERJ 15(2), or: cfies2017.sfds.asso.fr/. 


\title{
CHALLENGES AND INNOVATIONS IN STATISTICS EDUCATION
}

Multiplier conference of ProCivicStat

Szeged, Hungary, 7-9 September, 2017

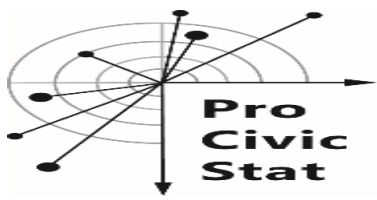

ProCivicStat contributes to understanding quantitative evidence about key social phenomena that permeate civic life. There will be workshops on digital tools, CODAP, Jupiter Notebook, on understanding statistics about society, on multivariate methods. Session topics are Developing statistical literacy, Effective and innovative teaching methods, Specific approach of ProCivicStat. The following key notes will form the background to the intense discussions:

Resources to support innovative teaching: conceptual maps, data sources, and visualisation tools (J. Ridgway, J. Nicholson, S. Teixeira, P. Campos);

Statistics for empowerment: opportunities and challenges (J. Ridgway).

More information in SERJ 15(2), or: www.eco.u-szeged.hu/english/research/conferencesworkshops/challanges-and-innovations-in-statistics-education/program/program.

\section{$14^{\text {th }}$ INTERNATIONAL CONFERENCE OF THE MATHEMATICS EDUCATION FOR THE FUTURE PROJECT}

Balatonfüred, Lake Balaton, Hungary, 10-15 September, 2017

The theme is Mathematics Education for the Next Decade: Heuristics and Challenges of Pólya and Lakatos. Apart from problem solving and modelling, use of technology, assessment, dealing with cultural differences, overcoming racial, gender and social barriers, teacher preparation, school organisation and classroom practices, the topic Using statistics in everyday life may specially interest researchers in statistics education. More information in SERJ 15(2), or: ecmiindmath.org/2016/06/12/mathematics-education-for-the-future-conference/.

\section{EDUCATION IN STATISTICS AT SCHOOL LEVEL STATISTIC DAYS OF THE AUSTRIAN STATISTICAL SOCIETY (ÖSG)}

\author{
University of Salzburg, 13-15 September, 2017
}

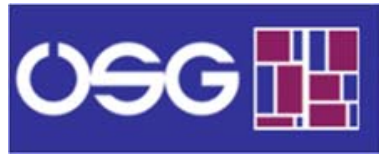

pre-service courses:

- Understanding uncertainty: probability education at the secondary level (R. Kapadia).

- Teaching stochastic by playing games (I. Engert-Oostingh).

- Applets to enrich the education in stochastics at school level (M. Borovcnik).

- Interactive experiments and videos for the elementary course in statistics (J. Mittag).

- Data that concern us - Elementary statistics education via official data (K. Krüger).

- The role of text and context in stochastic tasks (F. Schoberleitner).

- Pre-service courses in stochastics for future mathematics teachers (S. Götz).

More information: oemg-dmv-2017.sbg.ac.at/. 
TEACHING STATISTICS THROUGH INFERENTIAL REASONING

Online course, Friday Institute for Educational Innovation, NC State Univ., USA, Fall 2017, 5 units

This online professional development course is held by Hollylynne Lee; it is designed for teachers of statistics (grades 6-12 and post-secondary). Overall objectives of the course:

- Strengthen your understanding of how to engage students in statistical investigations;

- Explore a framework for guiding your teaching of statistical investigations;

- Use rich data sources and dynamic graphing tools to support data exploration;

- Examine the ways students reason with data to make inferences or claims;

- Apply a framework for inferential reasoning to your educational practices;

- Collaborate with colleagues near and far.

More information: place.fi.ncsu.edu/.

\section{ASA SYMPOSIUM ON STATISTICAL INFERENCE}

Bethesda, MD, USA, 11-13 October, 2017

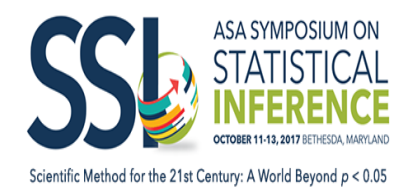

This symposium follows up on the historic ASA statement on $p$-values and statistical significance. Although the problems identified in the statement have been known for several decades, previous expressions of concern and calls for action have not fostered broad improvements in practice. Discussions will centre on specific approaches for improving statistical practice: Conducting or using research in the 21st century; Sponsoring, disseminating, and replicating research. More information:

ww2.amstat.org/meetings/ssi/2017/index.cfm?utm_source=informz\&utm_medium=email \&utm_campaign $=$ asa\&_zs $=$ LRaOe1\&_zl $=0 \mathrm{SNt} 3$.

\section{AUTUMNAL MEETING OF THE STUDY GROUP „STOCHASTICS“ HERBSTTAGUNG 2017 DES ARBEITSKREISES STOCHASTIK}

Frankfurt am Main, 10-12 November, 2017

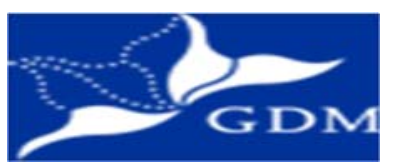

The theme of this year's meeting is "Effective teaching in stochastics from elementary school to the final exam ". As in previous years, young researchers are invited to present their dissertation projects.

Deadline for submission: 31 August.

More information: www.math.uni-frankfurt.de/ak-stochastik.

\section{JOINT MATHEMATICS MEETINGS}

San Diego, CA, USA, 10-13 January, 2018

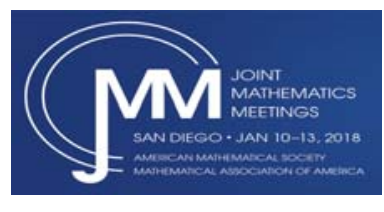

This is the largest mathematics meeting in the world. The programme is already well-developed and includes also general aspects of teaching mathematics.

Deadline for abstract submissions: 29 September, 2017.

For more information: jointmathematicsmeetings.org/jmm. 
2018 JOINT STATISTICAL MEETINGS

Vancouver, BC, Canada, 28 July-2 August, 2018

As usual with the largest statistics conference in North America, there will be presentations on statistics education organised by the Section on Statistical Education of the American Statistical Society.

More information: www.amstat.org/ASA/Meetings/Joint-Statistical-Meetings.aspx.

\section{$11^{\text {th }}$ CONGRESS OF EUROPEAN RESEARCH IN MATHEMATICS EDUCATION (CERME 11)}

Utrecht University, Utrecht, The Netherlands, 5-10 February, 2019

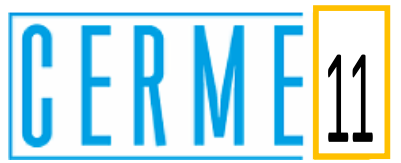

ERME has a strong working group on probability and statistics education. Local chair and co-chair of the next CERME are Marja van den Heuvel-Panhuizen and Michiel Veldhuis. The IPC will be chaired by Thomas Jankvist with co-chair Miguel Ribeiro. More information: cerme11.org/.

\section{OTHER PAST CONFERENCES}

\section{$10^{\text {th }}$ CONGRESS OF EUROPEAN RESEARCH IN MATHEMATICS EDUCATION (CERME 10)}

Dublin City University, Dublin, Ireland, 1-5 February, 2017

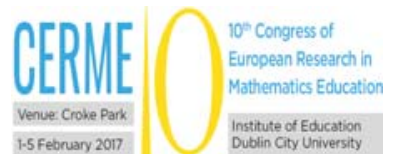

The proceedings of CERME 10 including the results of the working group on probability and statistics education will be published as in previous years.

More information:

www.mathematik.uni-dortmund.de/ erme/index.php?slab=proceedings.

\section{INTERNATIONAL CONGRESS ON MATHEMATICAL EDUCATION} (ICME 13)

Hamburg, Germany, 24-31 July, 2016

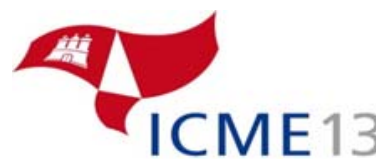

A selection of revised papers from the two Topic Study Groups related to IASE matters will be published by Springer by November 2017.

More information: www.springer.com/series/14352. 